\title{
PRELIMINARY ASSESSMENT
} OF FORT HOOD SOLARCOGENERATIONPLANT PERFORMANCE

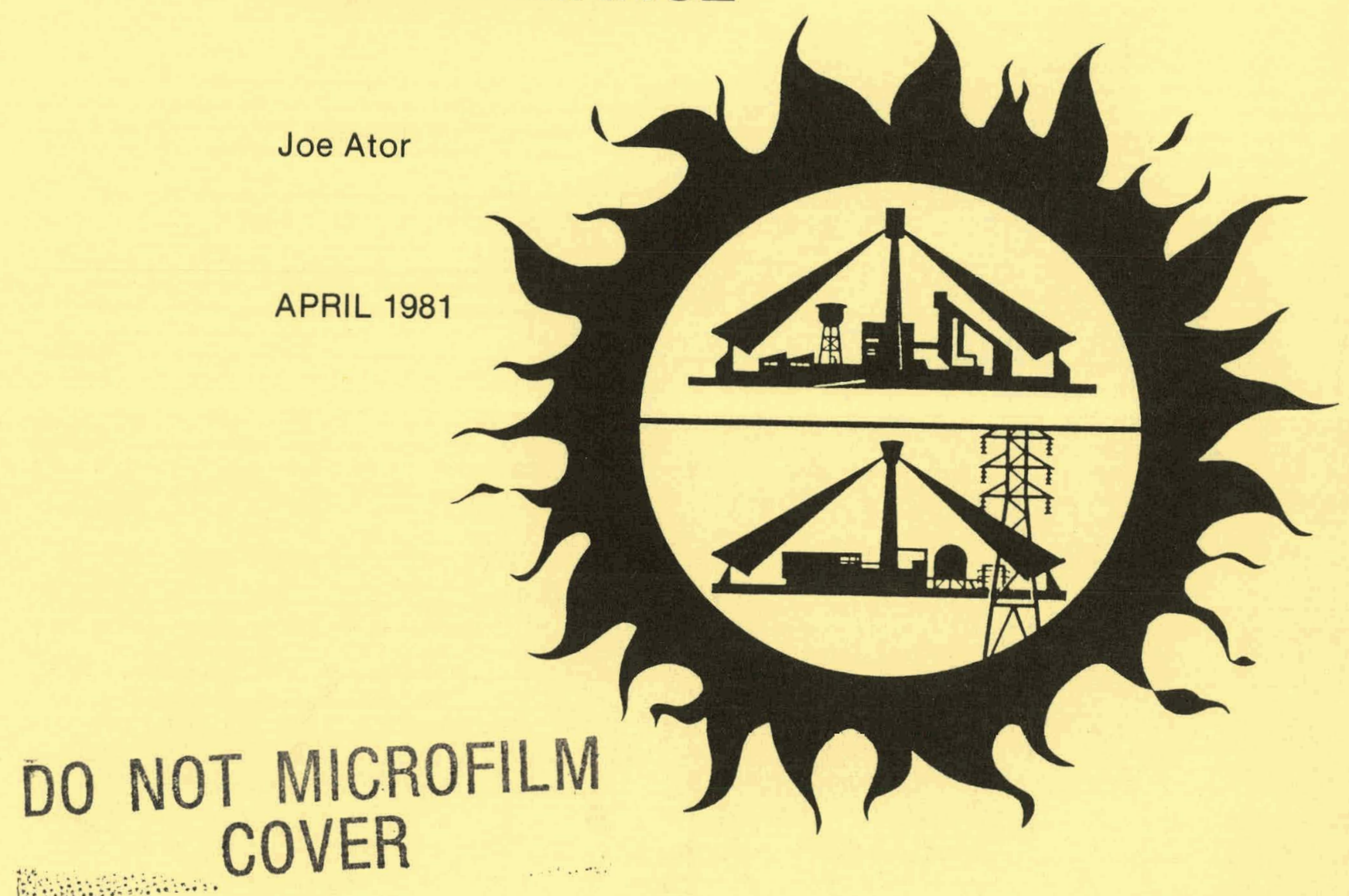

(4) the aerospace corporation El Segundo, California 


\section{DISCLAIMER}

This report was prepared as an account of work sponsored by an agency of the United States Government. Neither the United States Government nor any agency Thereof, nor any of their employees, makes any warranty, express or implied, or assumes any legal liability or responsibility for the accuracy, completeness, or usefulness of any information, apparatus, product, or process disclosed, or represents that its use would not infringe privately owned rights. Reference herein to any specific commercial product, process, or service by trade name, trademark, manufacturer, or otherwise does not necessarily constitute or imply its endorsement, recommendation, or favoring by the United States Government or any agency thereof. The views and opinions of authors expressed herein do not necessarily state or reflect those of the United States Government or any agency thereof. 


\section{DISCLAIMER}

Portions of this document may be illegible in electronic image products. Images are produced from the best available original document. 


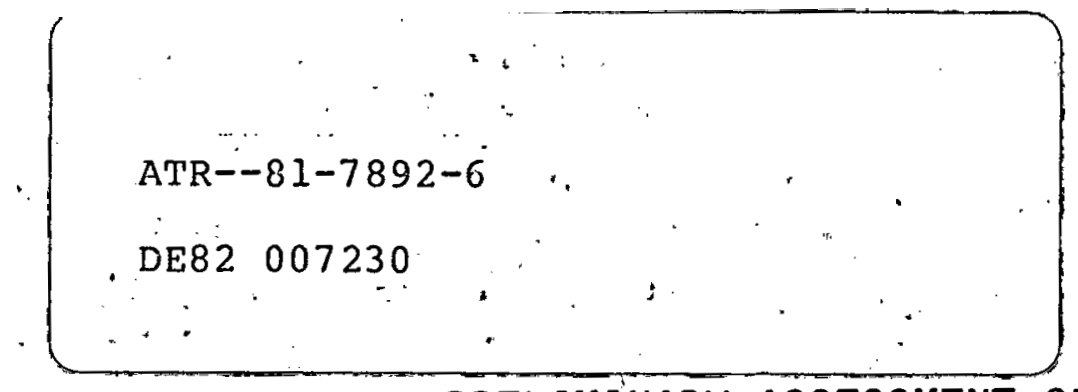

Aerospace Report Mo, ATR-८1(7€92)- 6

PRELIMINARY ASSESSMENT OF FORT HOOD

SOLAR COGENERATION PLANT PERFORMANCE

PREPARED FOR

THE DEPARTMENT OF ENERGY

SOLAR ENERGY DIVISION DOE/SAN!

CONTRACT MO. DE-ACO3 SFED 11427

APRIL 1981

PREPARED BY

JoE ATOR

ENERGY AND RESOURCES DIVISION

THE AEROSPACE CORPORATION

El SEGundo, California 


\section{THIS PAGE}

\section{WAS INTENTIONALLY \\ LEFT BLANK}


FOREWORD

This report presents a preliminary analysis of the Fort Hood Cogeneration project. This effort is a-part of the systems engineering task conducted by The Aerospace Corporation under DOE Contract No. DE-AC03-80SF 11427 under the overall cognizance of Mr. R. Hughey, Director, Solar Energy Division, and under the general direction of Dr. S. D. Elliott, Mr. L. Prince, and $\mathrm{Mr}$. F. Corona, Program Managers, DOE/SAN.

This report was prepared by Mr. J. Ator of the Energy Projects Group of the Energy and Resources Division of The Aerospace Corporation. Mr. S. D. Huffman is the General Manager and Mr. H. Bernstein is the Principal Director of the Group. Dr. Prem Mathur is the Principal Investigator for this contract. 
THIS PAGE

WAS INTENTIONALLY

$\mathbb{L E F T}$ BLANK 
Preliminary Assessment of Fort Hood Solar Cogeneration Plant Performance

TABLE OF CONTENTS

\section{- Page}

1. INTRODUCTION

2. DATA BASE FOR ANALYSIS

2.1 Site Information

2.2 Energy Requirements

2.3 Insolation Mode 1

3. PLANT MODEL AND ASSUMPTIONS 9

4. PERFORMANCE CALCULATIONS 13

4.1 Collectable Energy $\quad 14$

4.2 Energy Required for Load-Following Modes 14

5. ANNUAL ENERGY DISPLACEMENT RESULTS 18

6. SUMMARY 25

7. REFERENCES 29 


\section{INTRODUCTION}

An analysis has been performed to enable a preliminary assessment of the performance that can be expected of a solar thermal cogeneration system designed to serve a selected group of buildings at Fort Hood, Texas. A central receiver cogeneration plant, utilizing a molten salts mixture as the receiver coolant, heat transfer fluid, and storage medium, as described by McDonnel1 Douglas Astronautics Company (MDAC) in Reference A, has been assumed for this analysis.

The analysis herein reported is intended to provide a first-cut approximation of the plant performance to be expected with different sizes and operating modes. Although more investigation is required to ensure accurate results, this preliminary analysis is helpful in identifying upper and lower bounds of solar plant size and in indicating load-matching options which may be available.

\section{DATA BASE FOR ANALYSIS}

\subsection{Site Information}

The application currently being studied by $\mathrm{MDAC}^{*}$ is the use of a solar thermal central receiver cogeneration plant to supply a large share of the space heating, air conditioning, domestic hot water, and electricity needs of a 20-building Troop Housing Complex at Fort Hood. The layout of buildings and the approximate size and location of the solar collector field are shown in Figure 1. The area made available by the Fort Hood Directorate of Facilities Engineering for the collector field is approximately 15 acres. A previous study (Reference $B$ ) addressed the same application, using a distributed parabolic trough collector field, but it was restricted in scope to apply only to the loads of five of the 20 buildings in the complex: three barracks buildings, an administrative building, and the food services building, totalling $156,556 \mathrm{ft}^{2}$ in floor area.

*DOE/SAN Contract DE-AC03-8ISF 11495 


\section{FORT HOOD COMPLEX 87000}

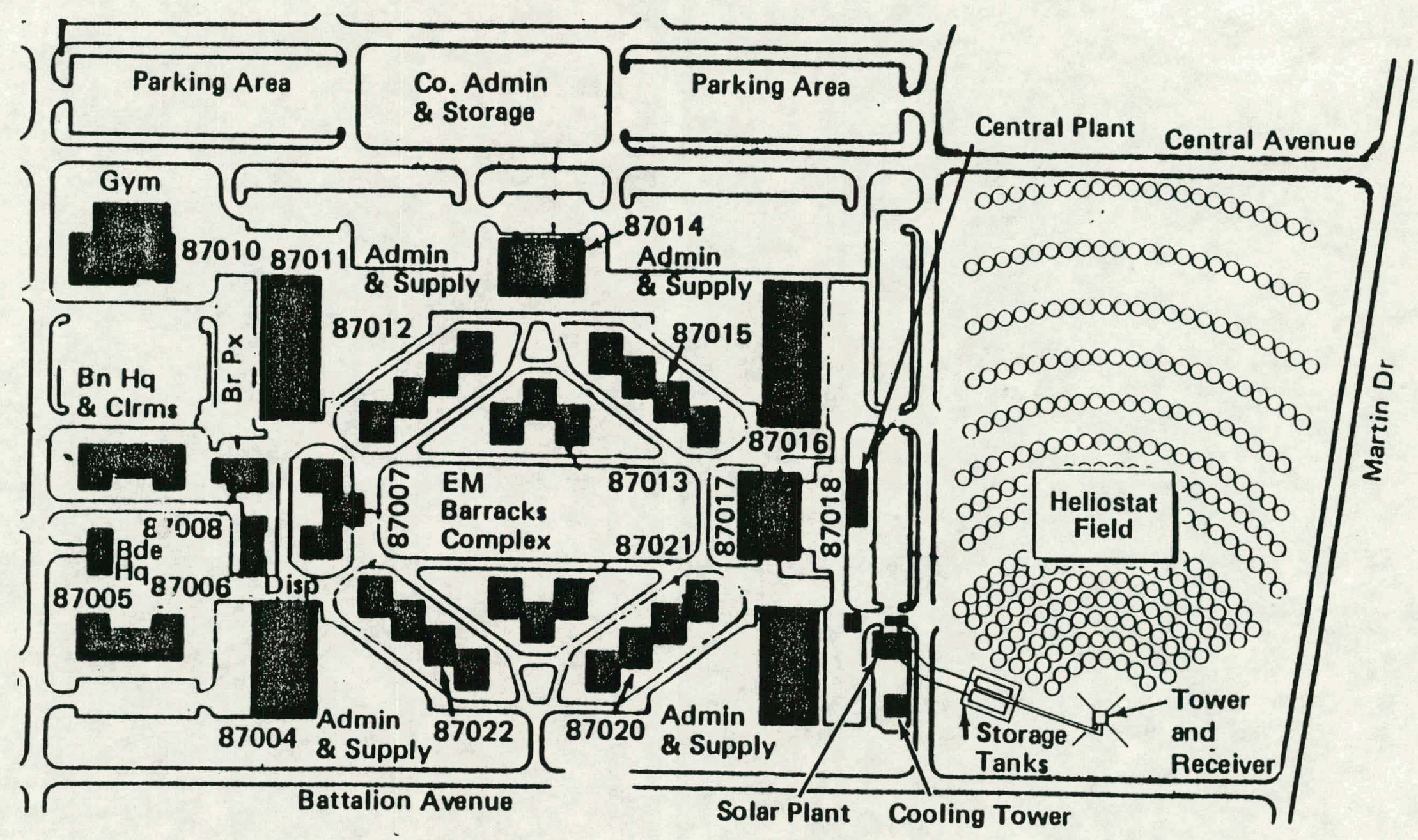

Bulldings _ $-\ldots-\ldots-\ldots-20(438,252 \mathrm{Sq}$ Ft Floor Ärea)

Barracks - - - - - ---7 (264,150 Sq Ft)

Occupancy $-\ldots-\ldots-\ldots-1650$ (Design) 


\subsection{Energy Requirements}

Figure 2 is a plot of the principal energy loads assumed for this analysis. They are taken directly from Reference 1 . Table 1 provides the same information in tabular form. An additional electrical load, not presented in Figure 2 or Table 1 , is the electrical parasitic load for the cogeneration plant, which will be estimated by scaling from the results reported in Reference $B$. The following paragraphs review the methodology by which they are estimated for this analysis.

The principal electrical parasitic loads in this application are listed in Table 2. They will be estimated in the order given in the table.

\section{- Heliostat Tracking}

From Reference C, page 209, a tracking power value of 56 watts per heliostat is given for the Barstow $10 \mathrm{MW}$ Pilot Plant collector field. MDAC has estimated a quantity of 266 heliostats for the Ft. Hood application (Reference 1). Thus, $56 \times 266=14,896$ watts, or approximately $15 \mathrm{~kW}$ tracking power is anticipated when the full field is in operation. Average daily tracking periods for winter and summer will be estimated at 6 hours and 9 hours, respectively. Tracking load during a winter month will be 6 hrs $\times 30$ days $\times 15 \mathrm{~kW}=2,700 \mathrm{kWh} / \mathrm{mo} .=2.7 \mathrm{MWh} / \mathrm{Mo}$. During a typical summer month it will be $9 \mathrm{hrs} \times 30$ days $\times 15 \mathrm{~kW}=4050 \mathrm{kWh} / \mathrm{mo}=4 \mathrm{MWh} /$ Mo .

\section{- Receiver Feedpump}

From Reference D, pages 4-107 through 4-109, a series of receiver feed pump power levels is given for $3-1 / 2$ year, $4-1 / 2$ year, and 6 year technology programs to develop and build a molten salts ( 1 MWe) central receiver system. The estimates are $50 \mathrm{~kW}, 30 \mathrm{~kW}$, and $16 \mathrm{~kW}$, in that order. For purposee of the present analysis we will use the 3-1/2 year technology estimate of $50 \mathrm{~kW}$, consistent with an early construction schedule. The receiver operating hours will be assumed identical to those of the heliostat field. Thus, for a winter month its power consumption will be $6 \times 30 \times 50=$ $9000 \mathrm{kWh} / \mathrm{Mo}$, or $9 \mathrm{MWh} / \mathrm{mo}$. And for a summer month it will be $9 \times 30 \times 50=$ $13.5 \mathrm{MWh} / \mathrm{mo}$ 


\section{MONTHLY POWER DEMANDS OF COMPLEX 87000}

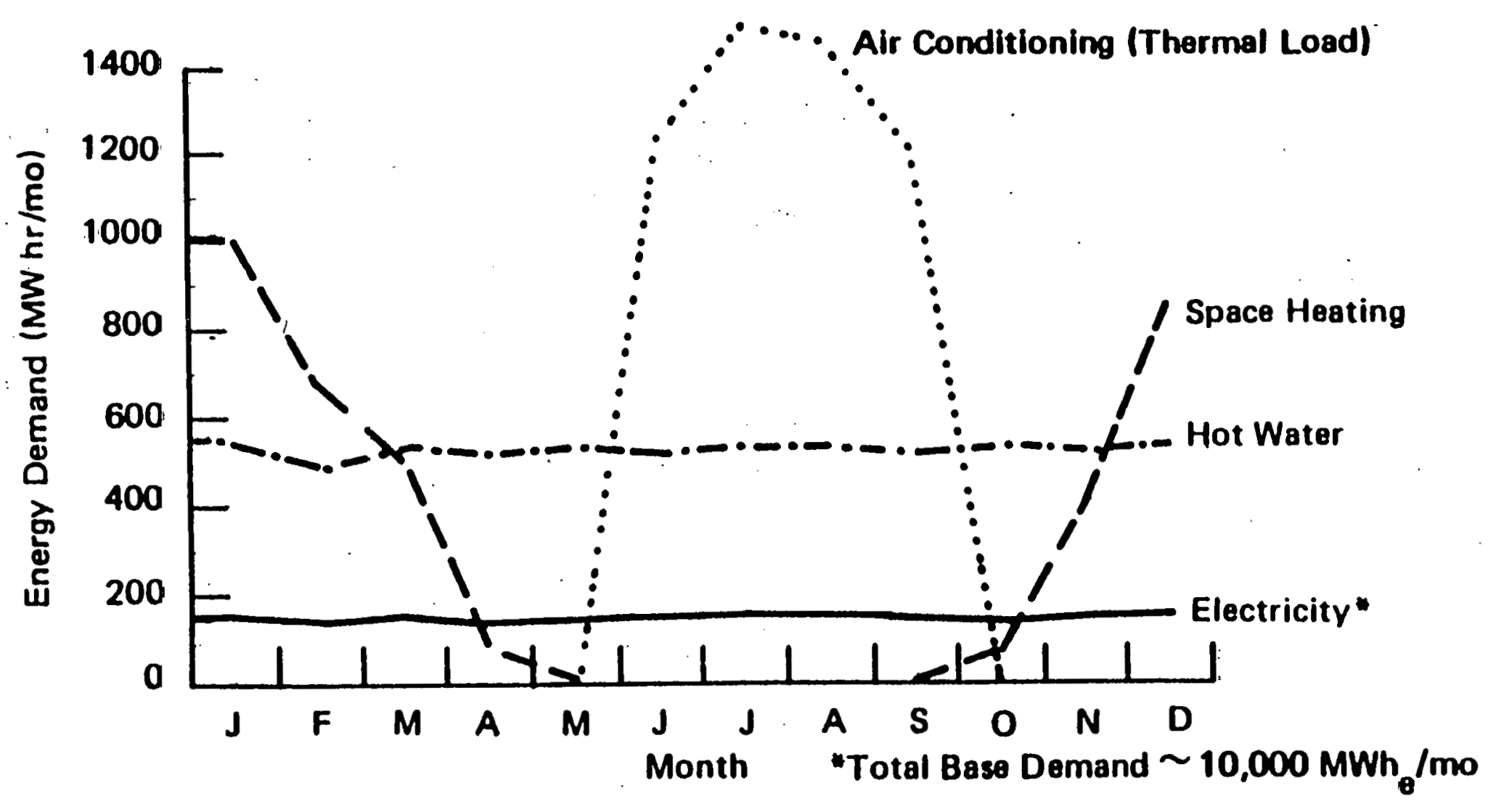


Table 1

ENERGY LOADS OF THE 87000 COMPLEX

(MWli/Mo.)

\begin{tabular}{|c|c|c|c|c|c|c|c|c|c|c|c|c|}
\hline & $\mathrm{J}$ & $\mathrm{F}$ & M & A & $\mathrm{M}^{\prime}$ & $\mathrm{J}$ & $\mathrm{J}$ & $\mathrm{A}$ & $\mathrm{S}$ & 0 & $\mathrm{~N}$ & D \\
\hline $\begin{array}{l}\text { Space } \\
\text { Heating }\end{array}$ & 1000 & 660 & 500 & 100 & 0 & 0 & 0 & 0 & 0 & 600 & 400 & 820 \\
\hline
\end{tabular}

Domestic

Hot Water

(DH'N)

$\begin{array}{llllllllllllll}500 & 500 & 540 & 510 & 520 & 520 & 520 & 520 & 520 & 520 & 520 & \frac{520}{6} \\ 1550 & 1160 & 1040 & 610 & 520 & 520 & 520 & 520 & 520 & 1120 & 920 & 1340\end{array}$

Space

Cooling

0

0

Electrical

(Baseload)

$141 \quad 156 \quad 151$

$\begin{array}{llll}156 & 151 & 156 & 156\end{array}$

$151 \quad 156 \quad 151$

156 
Table 2

PARASITIC LOAD ELEMENTS

\author{
Heliostat Tracking \\ Feceiver Feed Pump \\ Trace Heating \\ Steam Generator Feed Pump \\ Therma1 Storage Subsystem \\ Power Conversion Subsystem \\ Instruments and Controls \\ Computers and Displays
}


On page 4-107, Reference $D$, an estimate of 57 watts/meter is given for the "receiver loop" and 50 watts/meter for the "steam generator loop" trace heating loads, assuming a 3-1/2 year technology program. We will estimate 125 meters for the receiver loop. length and 25 meters for the steam generator loop. Thus,

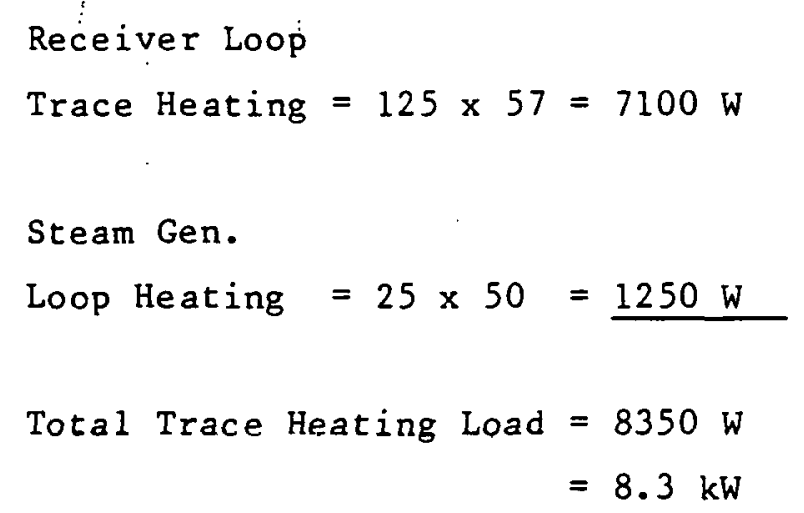

Trace heating will be a continuous load. For a typical month its consumption will be $8.3 \times 24 \times 30=5975 \mathrm{kWh} / \mathrm{mo}=6 \mathrm{MWh} / \mathrm{mo}$.

- Steam Generator Feed Pump

Also on page 4-107 of Reference D, an estimate of $7 \mathrm{~kW}$ is given for the drive power for the steam generator feed pump in a 3-1/2 year technology program. For purposes of this analysis, the steam generator will be assumed to operate continuously. Therefore, its monthly consumption will be estimated at $7 \mathrm{~kW} \times 24 \times 30=5040 \mathrm{kWh} / \mathrm{Mo} .=5 \mathrm{MWh} / \mathrm{mo}$.

- Thermal Storage Subsystem, Power Conversion Subsystem, Instruments and Controls, Computers and Displays

For this group of parasitic load elements, vol. 2, Part 2 of Reference B (page 4-63) provides estimates of the total power demands for a cogeneration system designed to meet the loads of 5 buildings of the 87000 Complex. An estimate of $42 \mathrm{~kW}$ is given for operation during the heating season and $62 \mathrm{~kW}$ during the cooling season. 
Those estimates will be scaled up for the MDAC central receiver application by simply using a ratio of the total floor area to be served by the respective plant designs, since both employ topping cycle steam generators and use extraction and exhaust steam for powering absorption chillers and the space heating subsystem. The floor area ratio is

$$
\frac{438,232 \mathrm{ft} 2}{156,556 \mathrm{ft}^{2}}=2.8
$$

Therefore; for this group of plant components the heating season load will be $2.8 \times 42 \mathrm{~kW}=117.6 \mathrm{~kW}$, and the cooling season load will be $2.8 \times 62$ $=173.6 \mathrm{~kW}$. A "load factor" of 0.85 will be assumed in each case to account for the fact that the cooling and heating demands will not be at their peak the entire season in which they fall. Thus, for a typical winter month the estimated demand is $117.6 \mathrm{~kW} \times 24 \times 30 \times 0.85=71,971 \mathrm{kWh} / \mathrm{mo}=72 \mathrm{MWh} / \mathrm{Mo}$.

For summer months, the estimated demand for this group of components will be $173.6 \mathrm{~kW} \times 24 \times 30 \times 0.85=106,243 \mathrm{KWh} / \mathrm{Mo} .106 \mathrm{MWh} / \mathrm{Mo}$.

The parasitic loads thus estimated will now be summarized according to their approximate duty cycles and seasons of operation to arrive at monthly totals for the winter and summer seasons, assuming 30-day months.

\begin{tabular}{ll} 
Winter & $\begin{array}{l}\text { Summer } \\
\text { Months }\end{array}$ \\
\hline (MWh/Mo.) & $\underline{\text { (MWh/Mo.) }}$ \\
\hline
\end{tabular}

Heliostat Tracking:

Receiver Feed Pump:

Trace Heating:

Steam Gen.Feed Pump:

Thermal Storage, Power

Conversion, Instruments

Controls, Computers, Displays

Total Parasitic Loads
2.7

9.0

6.0

5.0

$\frac{72.0}{94.7}$

$$
4.0
$$$$
13.5
$$

6.0

5.0 
These results will be rounded off to $95 \mathrm{MWh}$ and $135 \mathrm{MWh}$. For months with a different number of days, they will be adjusted upward and downward appropriately.

\subsection{Insolation Mode 1}

The insolation available for each month in the Fort Hood model year is taken from Reference B, Vol. II, Part 2, page 6-22. The monthly values are listed in Table 3. These insolation values statistically take into account the totally overcast days and partly cloudy days which would be present in an hourly insolation model.

\section{PLANT MODEL AND ASSUMPTIONS}

The major elements in the cogeneration system proposed by MDAC are shown in the block diagram in Figure 3, taken from Reference A. A simplified model of the system showing its major functional components and unidirectional energy flow scheme through the plant is presented in Figure 4, with some of the key system parameters. The parameters in the model are defined, evaluated, and interrelated as follows:

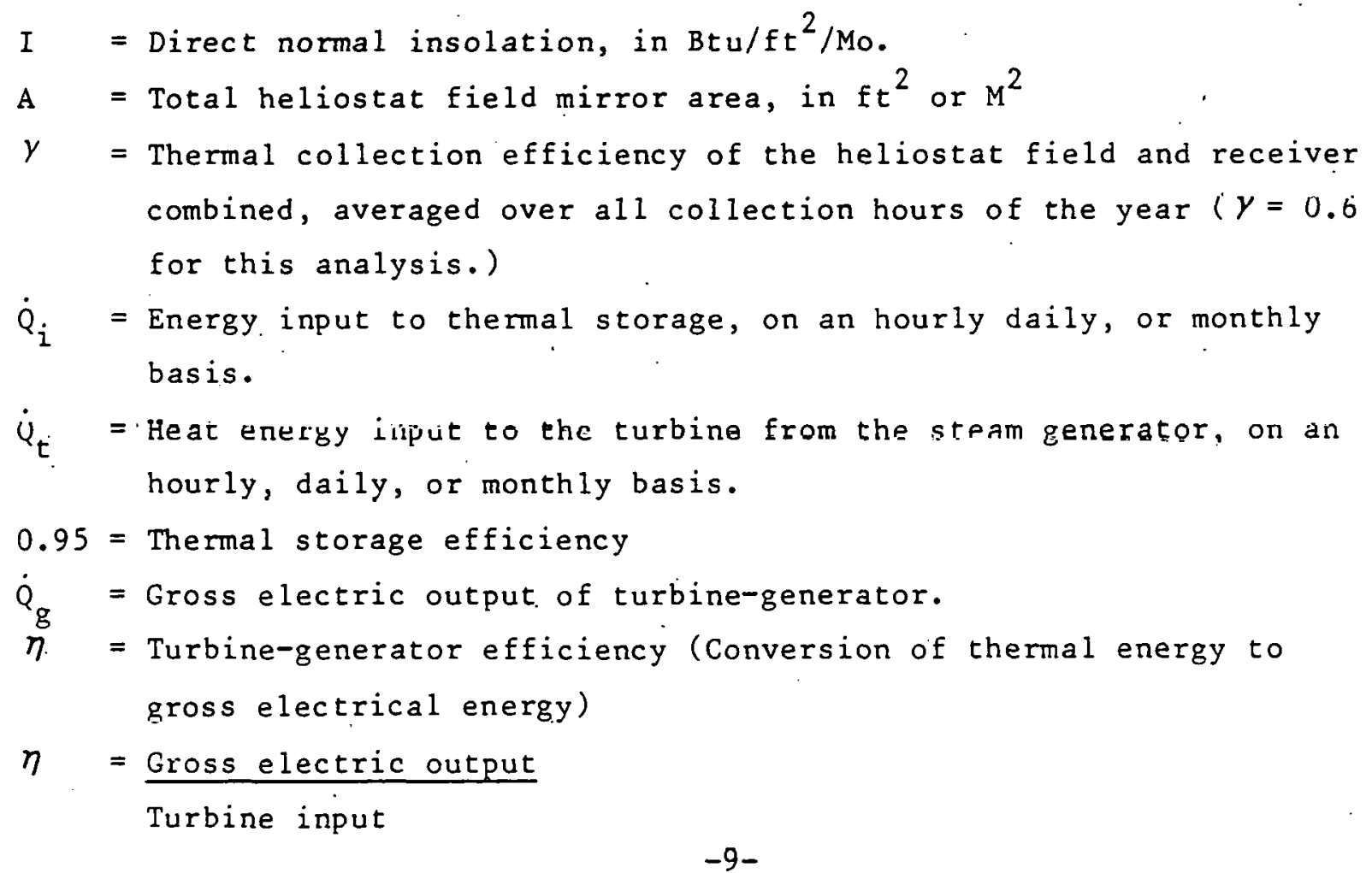


TABLE 3

MONTHLY AVAILABLE DIRECT NORMAL INSOLATION AT FORT HOOD

$$
\left(10^{3} \mathrm{Btu} / \mathrm{ft}^{2} / \mathrm{Mo} .\right)
$$

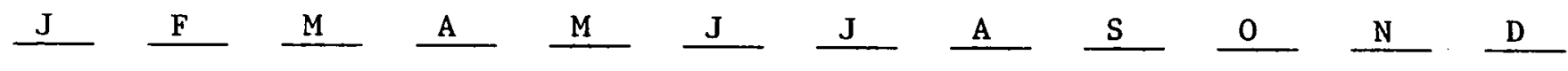

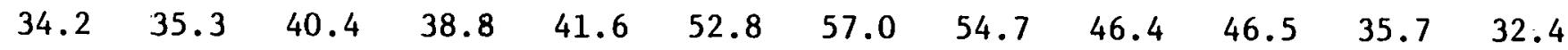




\section{MAJOR ELEMENTS SOLAR COGENERATION SYSTEM}

Power

Conversion

Collection

Storage

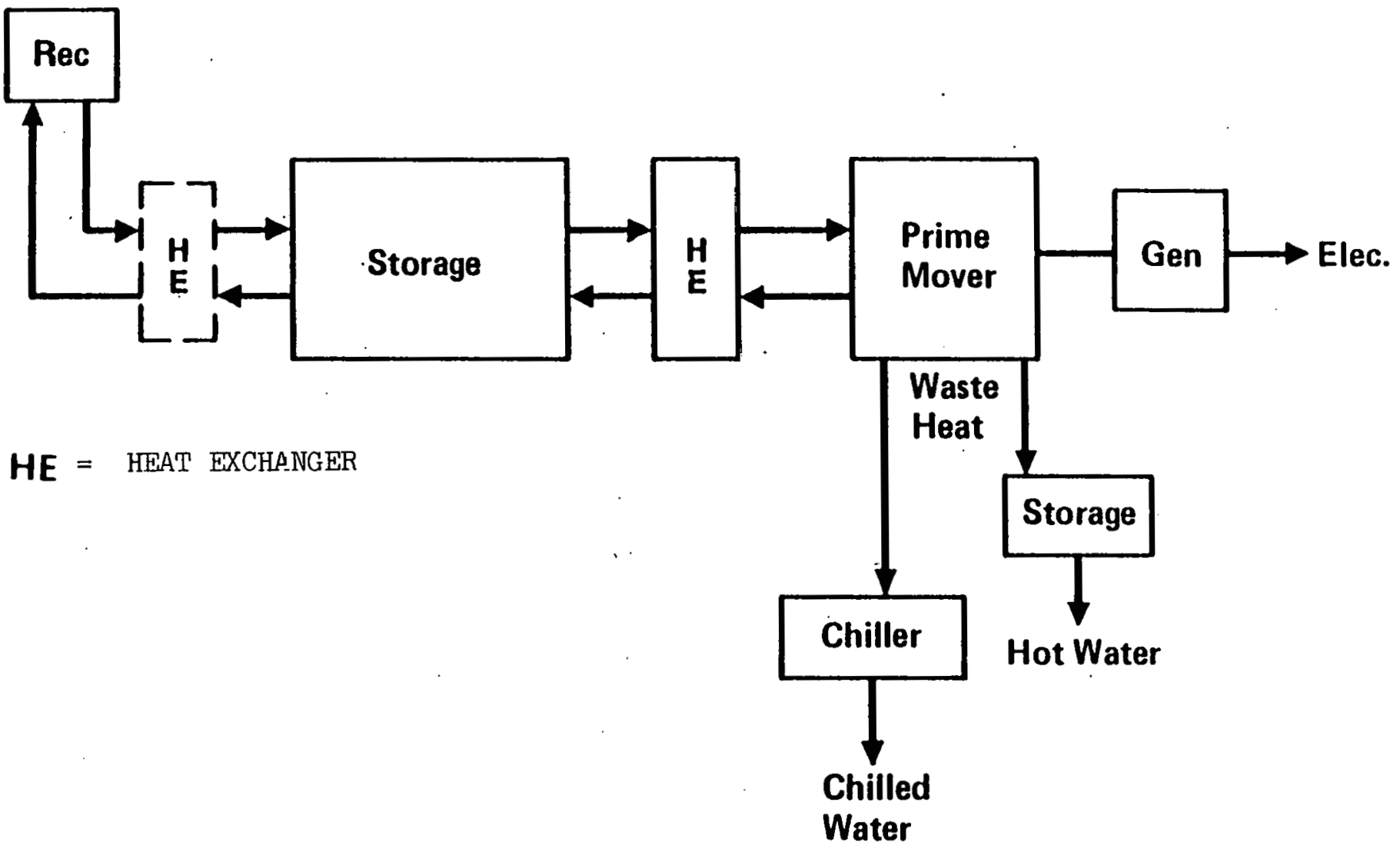


Figure 4

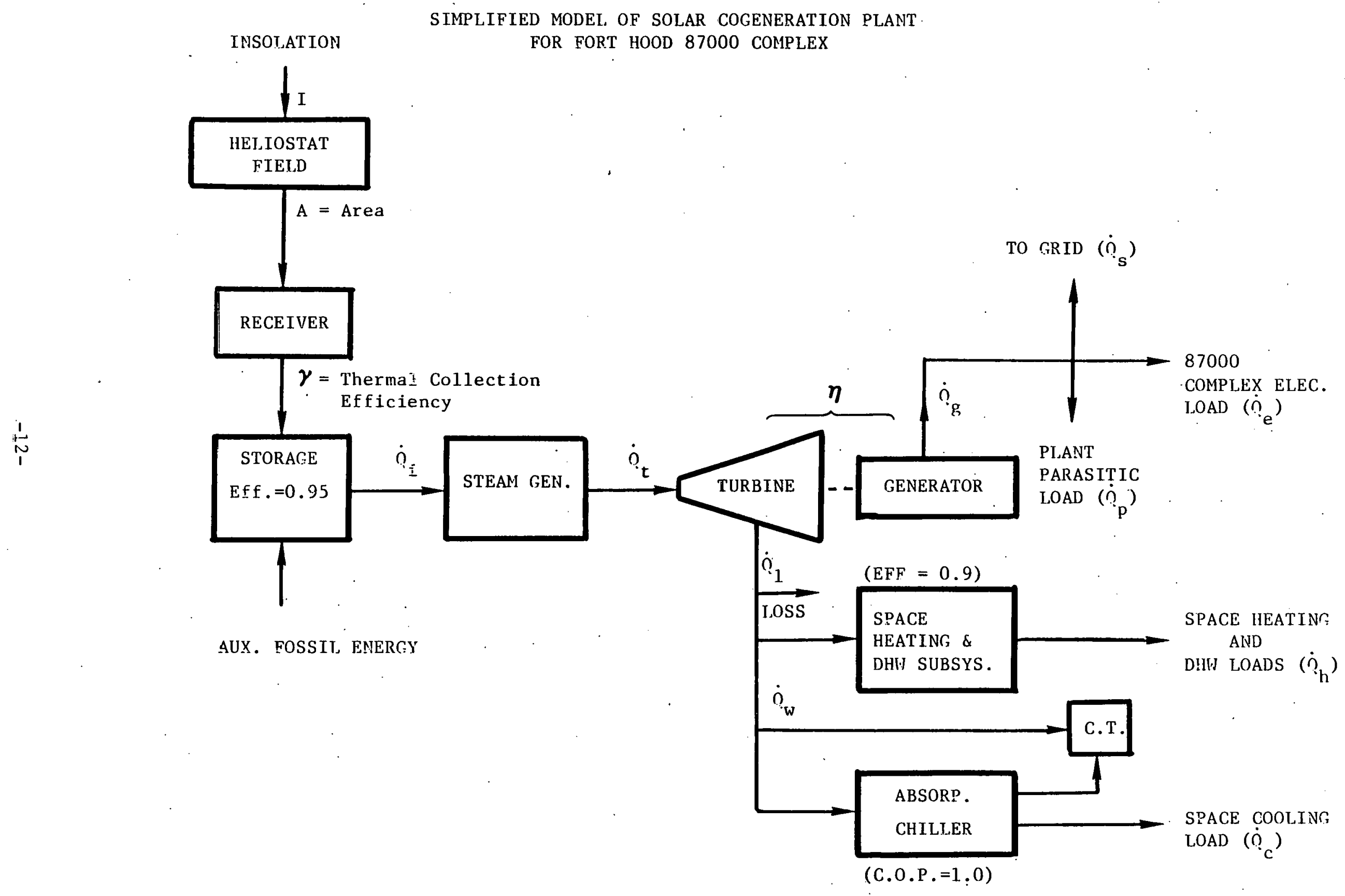


$\dot{Q}_{s}=$ Excess electricity delivered to grid

$\dot{Q}_{e}=87000$ Complex load (called baseload)

$\dot{Q}_{p}=$ Plant parasitic load (as estimated in Section 2).

$\dot{Q}_{1}=$ Thermal losses in turbine generator and system piping

$\dot{Q}_{w}=$ Waste heat (occurs when thermal loads are at a minimum)

$\dot{Q}_{h}=$ Space heating and domestic hot water loads of the 87000 Complex

$\dot{Q}_{c}=$ Space cooling load of 87000 Complex (heat to be extracted from the buildings)

The basic energy flow equations are:

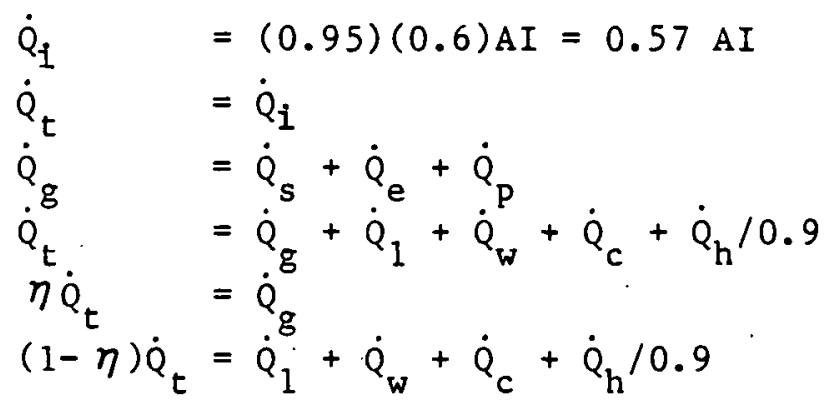

For this analysis, performance will be evaluated for $\eta$ values of 0.10 , 0.15 , and $0.20^{*}$ It is an implicit assumption in the performance evaluation that, for field sizes large enough to meet the highest average daily (full 24 hours) thermal energy demand using only the solar energy collectable during the 6-9 hour daylight period, the thermal storage capacity is made large enough for the plant to meet thermal loads occurring from the time collector subsystem operation ends until it can be resumed the next day. The storage size is then scaled down for system sizes with reduced solar energy collection, in proportion to the reduction in solar input. The method is, in effect, a simplified version of more detailed (hour-by=hour) simulation approaches.

* Reference $E$ indicates that a typical industrial steam turbine cogeneration. system, with a steam outlet pressure of $50 \mathrm{psi}$, will have an $\eta$ value of about 0.18 .

Reference $F$ (page 212) indicates $\eta$ values of 0.08 to 0.16 can be expected with steam turbine topping cycle cogeneration systems, depending on the throttle conditions under which the turbine is operated. With variable extraction turbines, it may be possible to realize relatively high turbine generator efficiency during periods of low thermal demands, thus achieving a high average $\eta$ on a monthly or annual basis. 
The above energy flow equations may be treated as applying on a daily basis, so that the energy required to satisfy the average daily loads during a given month can be calculated from the mean daily insolation for that month. Depending on the collector area selected, supplementary energy may be required from backup sources. Once the equations are evaluated using such daily load and insolation values, they are extended to a monthly basis by multiplication by the appropriate number of days for each month.

Expressions for the amount of energy allocated to electric power generation, thermal losses, and for meeting thermal loads on a daily basis are given in Table 4 , in terms of $\dot{Q}_{t}$, the total daily energy input to the turbine. All daily electric and thermal energy demands are thus reflected back to the turbine input. That provides a convenient point in the simplified plant model at which to compare energy demands with energy availability.

\subsection{Collectable Energy}

Using the insolation data in Table 3 the average daily solar energy which can be collected and delivered to the turbine input each month in the year at Fort Hood was calculated by application of Equations (1) and (2). The results are plotted in Figure 5 in the form of annual profiles for 4 different heliostat field sizes.

\subsection{Energy Required For Load-Following Models}

It is informative to plot the profiles of electric and thermal loads on an annual basis, in terms of the magnitude of the loads as reflected at the turbine input. The daily ( 24 hour) values of $\dot{Q}_{e}$ required to mest either the grnss electric generation demand, $\dot{Q}_{y}$, or the total thermal load can be estimated by use of Equations (5) and (6), respectively, using the data in Table 1. Thus, for the proposed cogeneration plant to operate in an electric load-following mode, we need to continuously satisfy the equation:

$$
\dot{Q}_{t}=\dot{Q}_{g} / \eta
$$


Table 4

DAILY ENERGY ALLOCATIONS WITH DIFFERENT TURBINE-GENERATOR EFFICIENCIES

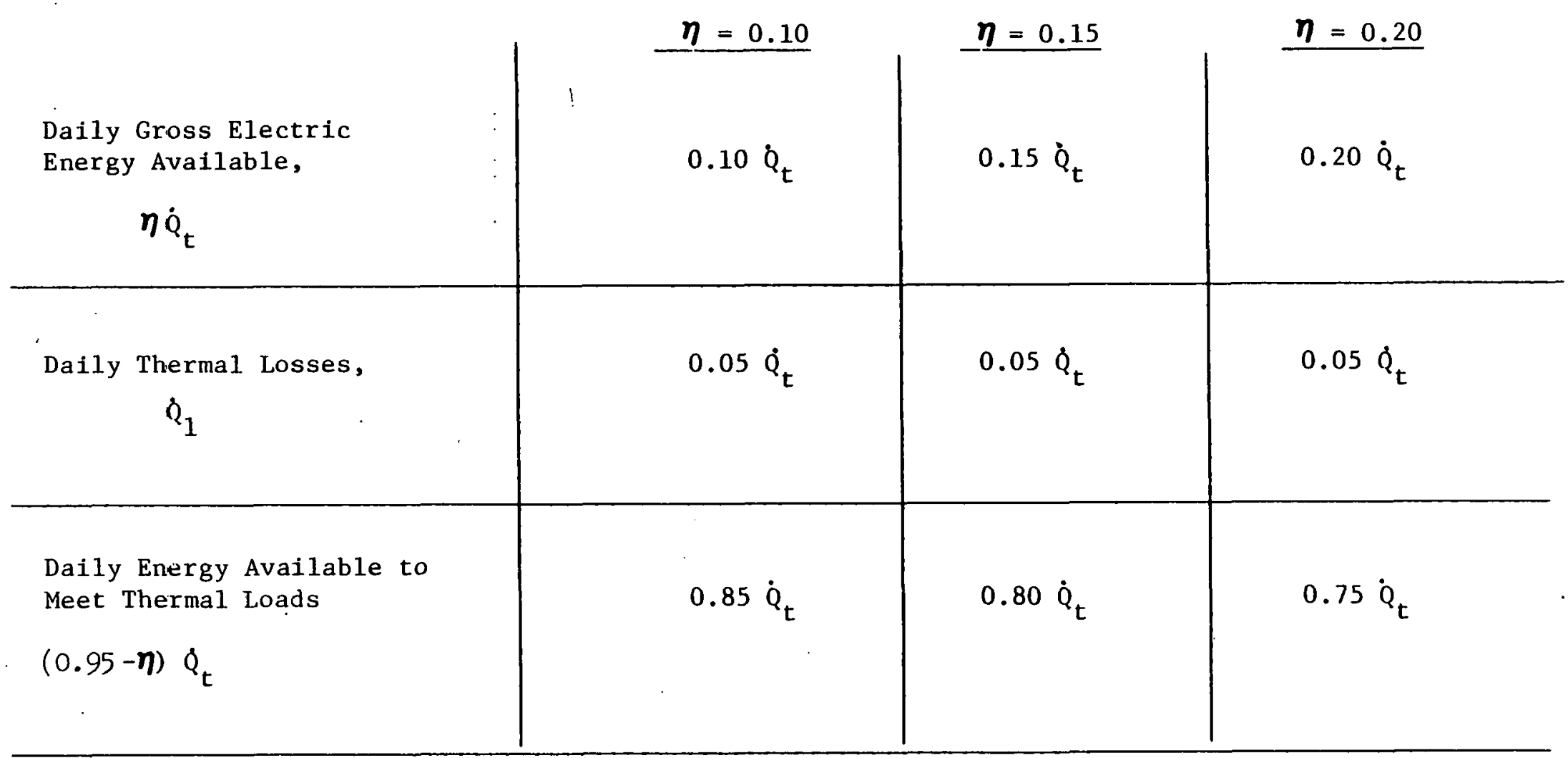


Figure 5

AVERAGE DAILY COLLECTABLE ENERGY

CONCEPTUAL SOLAR THERMAL CENTRAL RECETVER SYSTEM

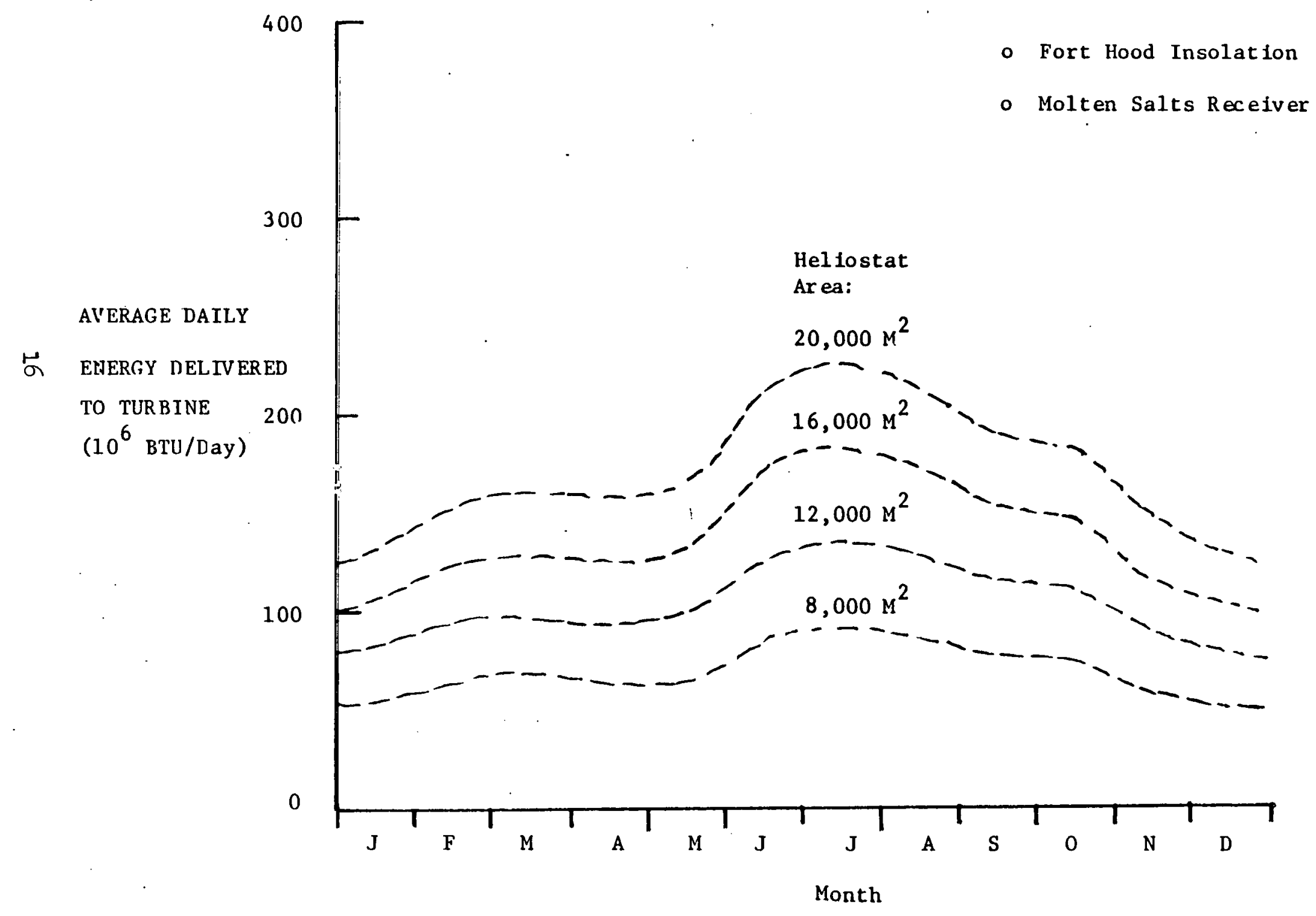


and in order for the plant to continuously meet the combined thermal loads, we must satisfy the equation:

$$
\dot{\vec{Q}}_{t}=\frac{\dot{\mathrm{Q}}_{1}+\dot{\mathrm{Q}}_{\mathrm{w}}+\dot{\mathrm{Q}}_{\mathrm{h}} / 0.9}{1-\eta}
$$

The annual profiles of $\dot{Q}_{t}$ for electric load-following, as determined by Equation 7 and the conditions assumed in Table 4, are plotted in Figure 6. Also shown on the same plot are the profiles of average daily energy deliverable to the turbine from heliostat fields ranging from $8,000 \mathrm{~m}^{2}$ to $20,000 \mathrm{~m}^{2}$ in total mirror area. Visual inspection shows that, to operate in an electric load-following mode with essentially $100 \%$ dependence on solar energy, a field size of at least $16,000 \mathrm{~m}^{2}$ is needed. (Adjustments for reduced heliostat tracking power with smaller field sizes have not been included, since it represents less than $3 \%$ of the parasitic load).

Similarly, the annual profiles of $\dot{Q}_{t}$ for thermal load-following, as determined by Equation (8) and the conditions assumed in Table 4 are plotted in Figure 7. The profiles of average daily energy deliverable to the turbine with the use of different sized heliostat fields are also shown.

As mentioned in Section 2.1, the available area for a heliostat field is limited to approximately 15 acres. That is based on a current position of the Fort Hood Directorate of Facilities Engineering, and it is preferable that planners of the solar energy plant observe that constraint. Assuming a maximum "packing fraction" of 0.25 - 0.27 , a practical upper limit on total heliostat mirror area is about $16,000 \mathrm{~m}^{2}$. The prospects for meeting the electric and thermal loads with such a field are indicated by Figure 8 (electric load) and Figure 9 (thermal loads) for typical cases. The energy deficiency or "shortfall" is indicated by the cross-hatched area in each case. The amount of monthly energy shortfall can be readily calculated and totalled for the full year in each case, to allow calculations of the annual percentages of electric and thermal loads which can be displaced by solar-derived energy as a function of field size. 
TURBINE INPUT DEMAND FOR ELECTRIC LOAD-FOLLOWING COMPARED WITH AVAILABLE ENERGY

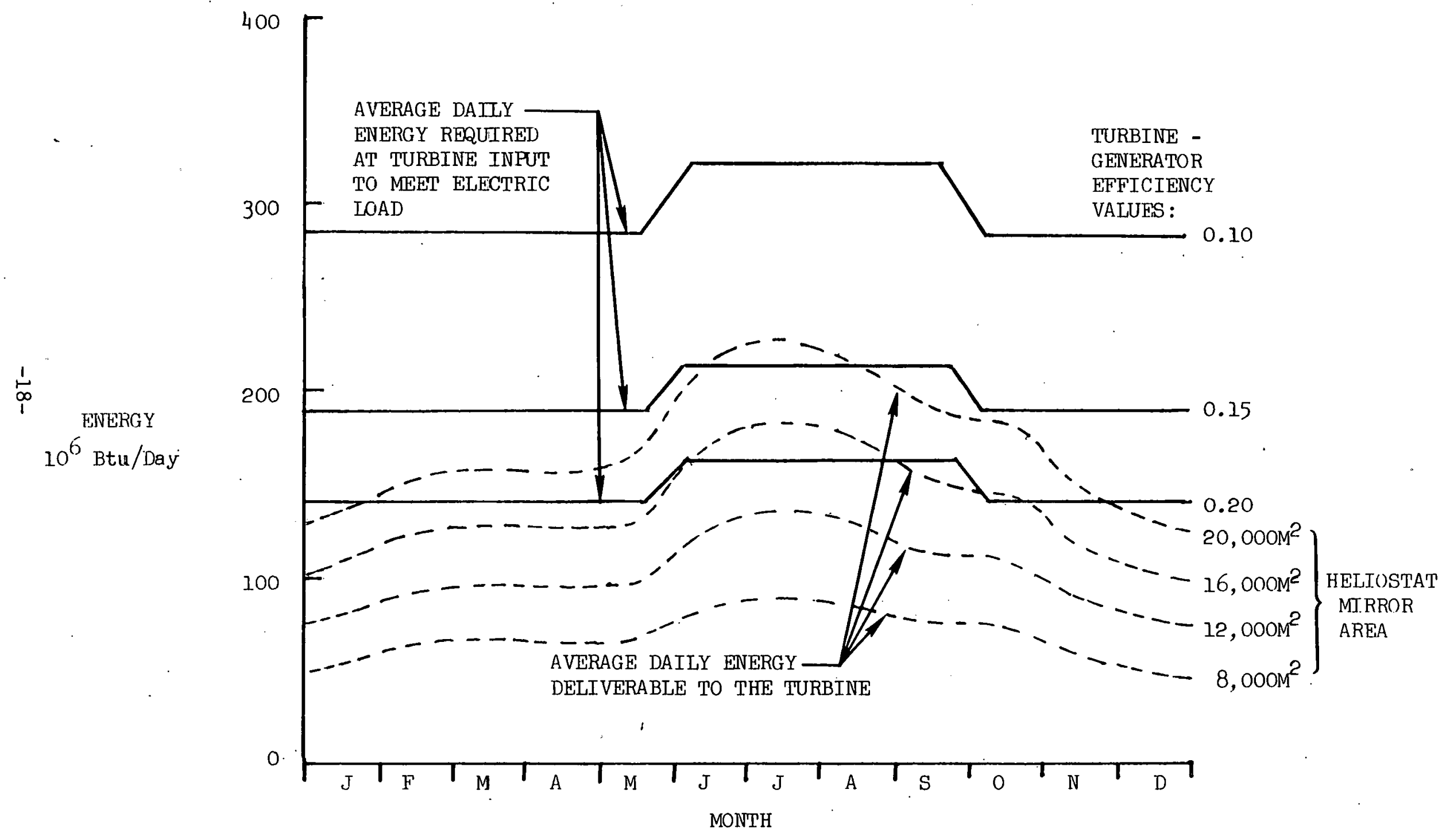


TURBINE INPUT DEMAND FOR THERMAL LOAD-FOLLOWING COMPARED WITH AVAILABLE ENERGY

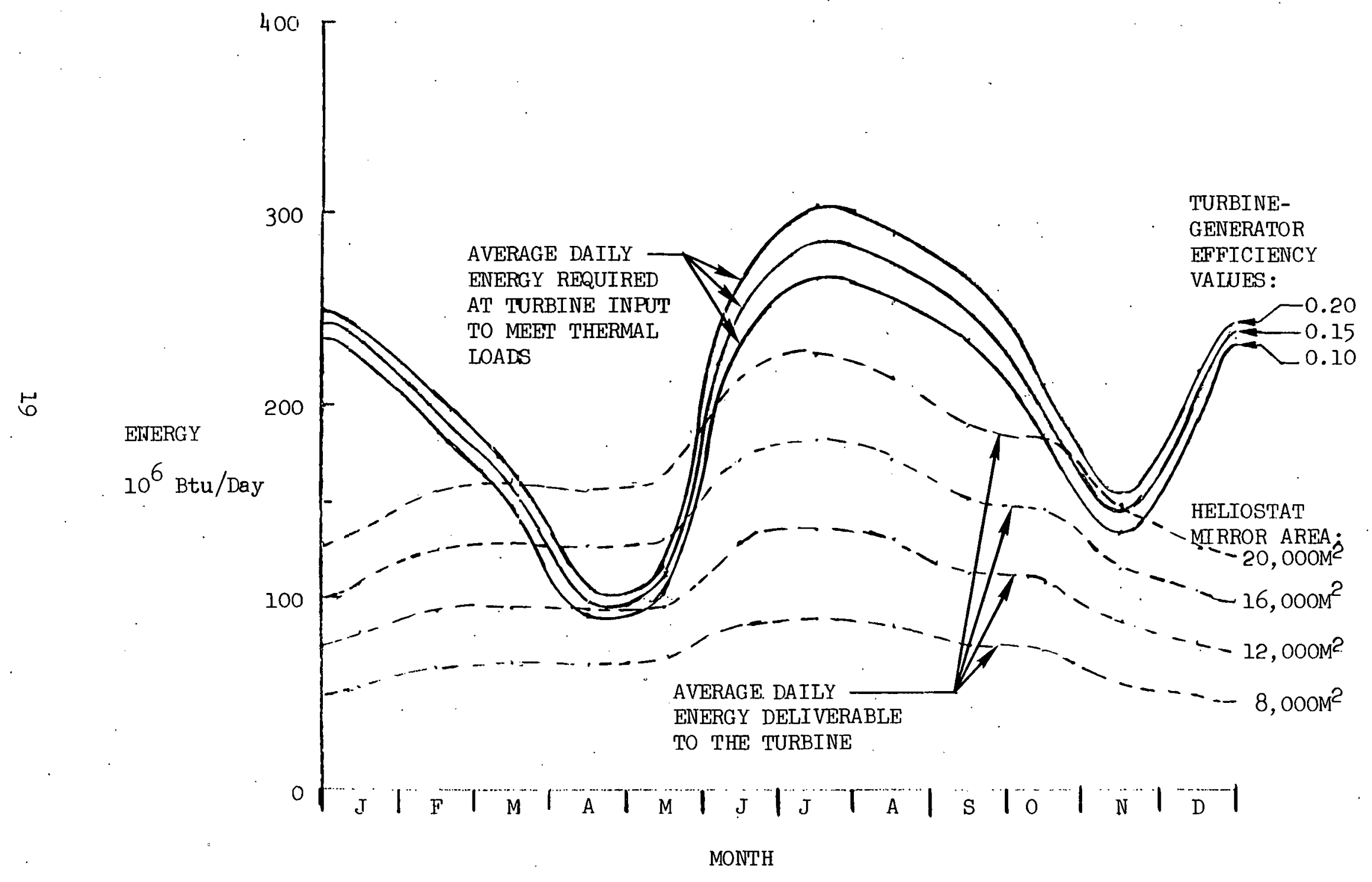


Figure 8

ELECTRIC DEMAND vs. ENERGY AVAILABLE FROM SOLAR

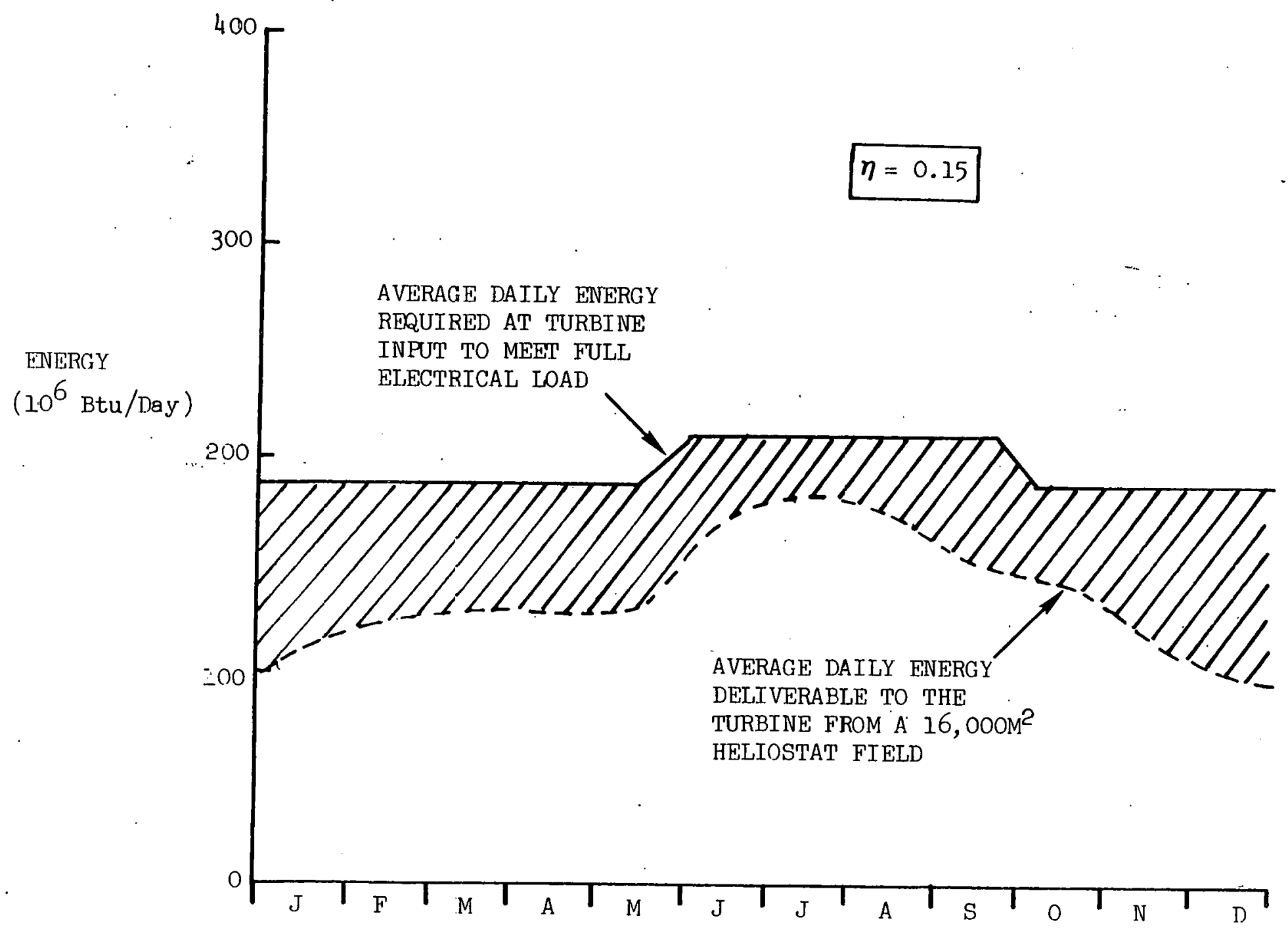


Figure 9

THERMAL DEMAND vs. ENERGY AVAILABIE FROM SOLAR

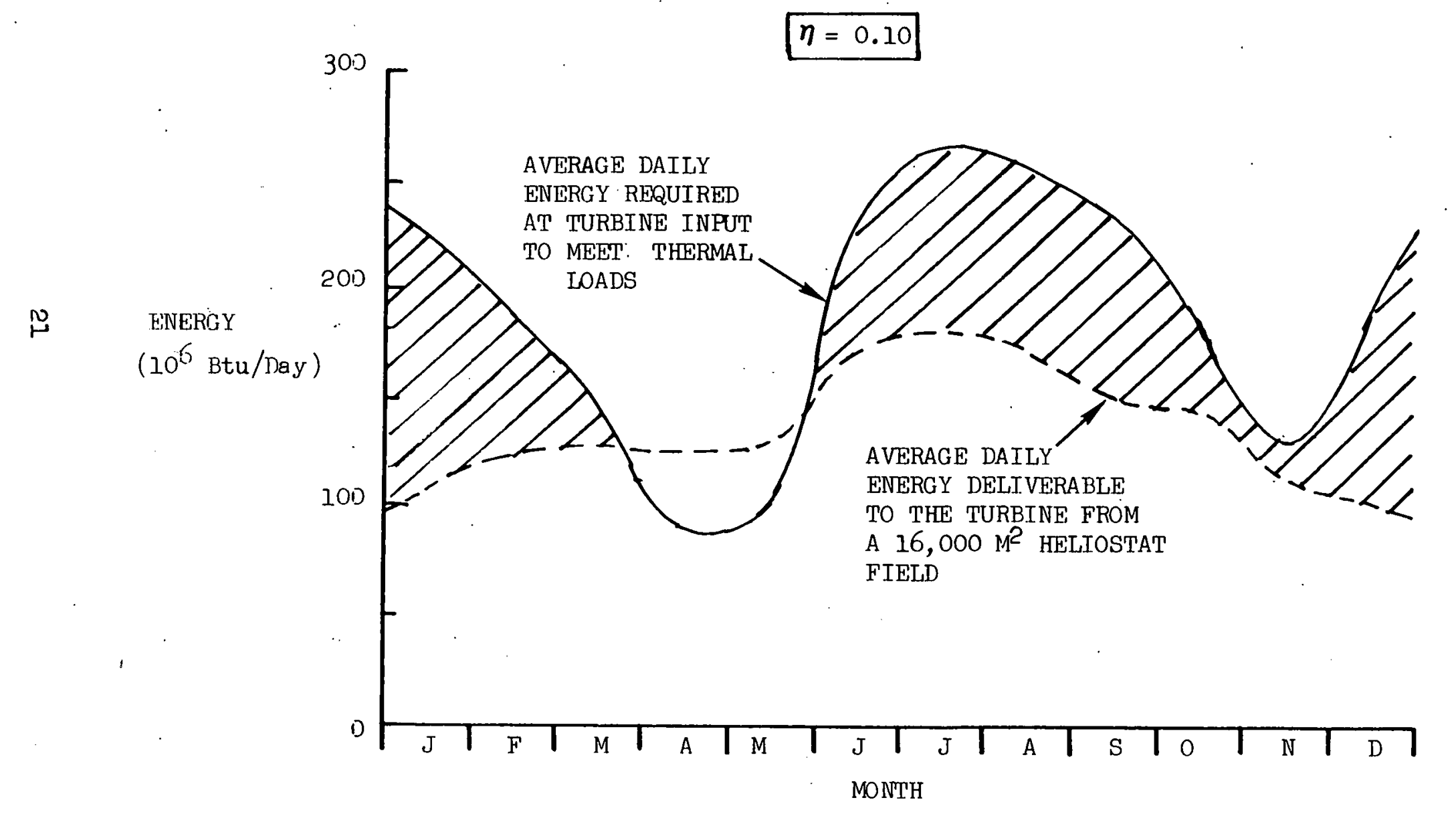




\section{ANNUAL ENERGY DISPLACEMENT RESULTS}

Following the procedures referenced in Section $A$, the percentages of the annual electric and thermal loads of the 87000 complex which a solar cogeneration plant can displace were calculated as a function of field size for different assumed values of $\eta$. The results are presented in Figures 10,11 , and 12 .

The results depicted in Figures 10,11 , and 12 are summarized in Figure 13, with percentage annual load displacement shown as a function of the turbine-generator efficiency and the heliostat field size selected. Thus cogeneration plant performance with a given average turbine-generator efficiency can be read off the curves.

As a cross check it is noted that the initial MDAC design concept (Reference A) was predicted to generate 2850 MWh of electricity per year with a total heliostat area of $15,160 \mathrm{~m}^{2}$. That would correspond to a $90 \%$ displacement of the gross electric demand used in the present analysis. Examination of Figure 13 indicates an average turbine-generator efficiency of about 0.20 would have to be realized to achieve that performance, which would probably stress the state of the art in the technology of small to medium-sized turbine-generators. The cross check may not be valid since the subsystem efficiencies of the MDAC design were not given in Reference $A$ and in fact may be far different from those which were assumed for the mathematical plant model shown in Figure 4.

Ideally, a cogeneration plant application where supply steam is continuously available will have a thermal-to-electric (T/E) load ratio exactly matching the respective thermal and electric energy outputs of the plant's power conversion subsystem. Unfortunately that situation is never realized in practice, so some compromises must be made. For the present application, it is informative to plot the ratio of gross thermal load to gross electric load exhibited by the 87000 complex on a month-by-month basis, which ranges from 4.5 to 13.3 during the year (ignoring $\dot{Q}_{1}$ and $\dot{Q}_{w}$ values). 
PERFORMANCE OF CENTRAL RECEIVER COGENERATION SYSTEM

AT THE FORT HOOD 87000 COMPLEX $(\eta=0.10)$

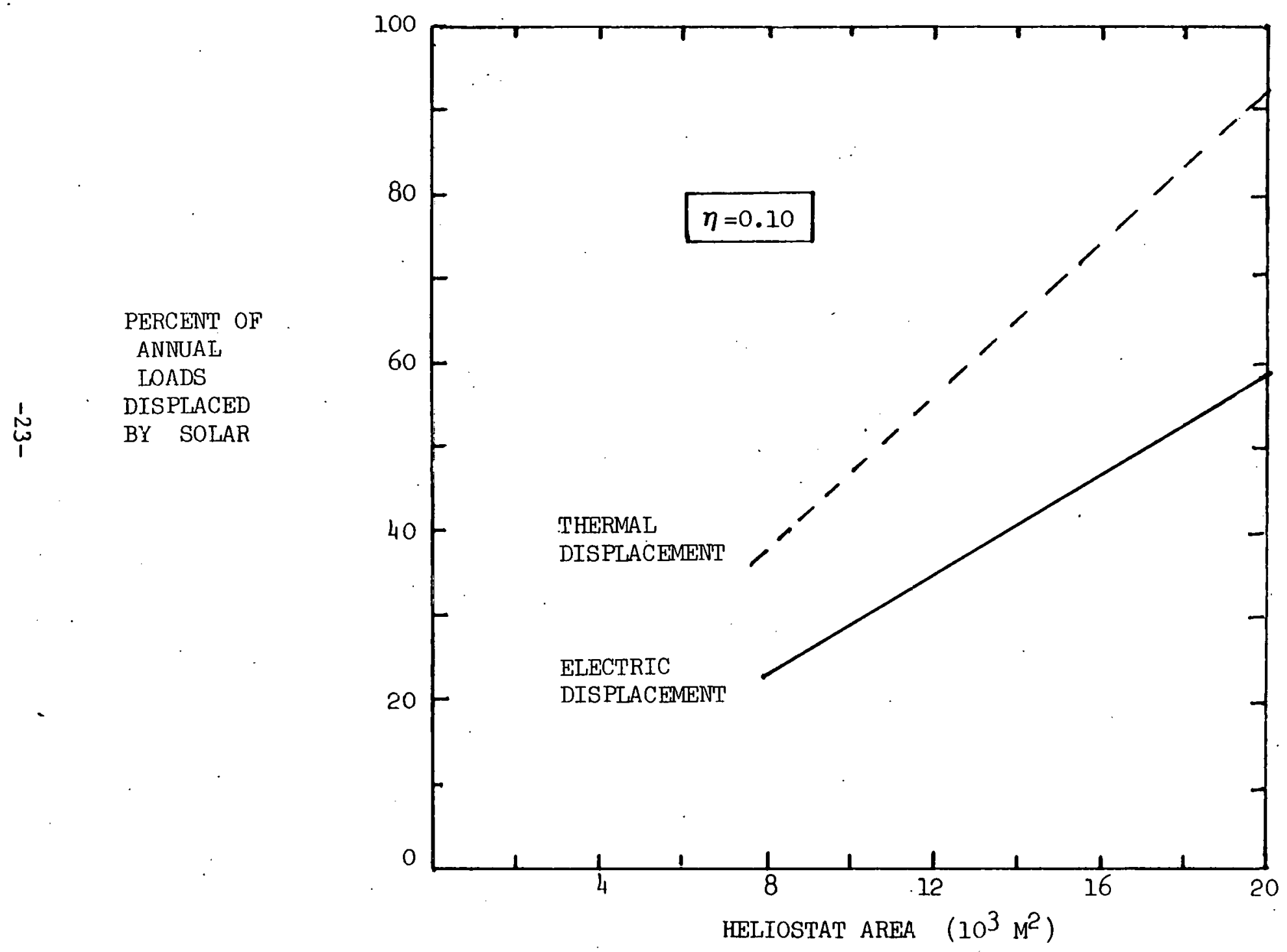


PERPORMANCE OF CENTRAI RECEIVER COGENERATION SYSTEM AT THE FORT HOOD 87000 COMPLEX $(\eta=0.15)$

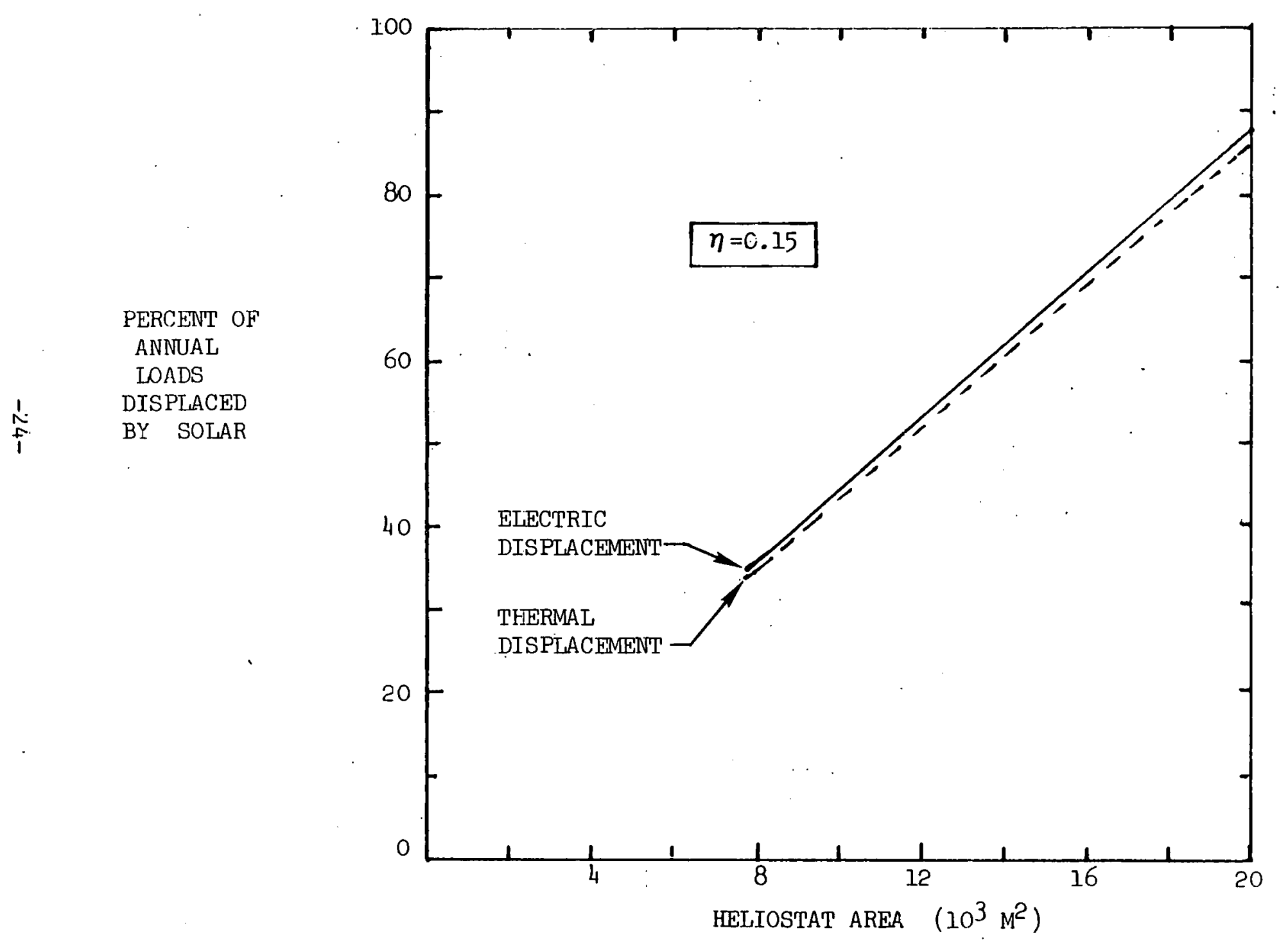


- igu 2

PERFORMANCE OF CENTRAL RECEIVER COGENERATION SYSTEM

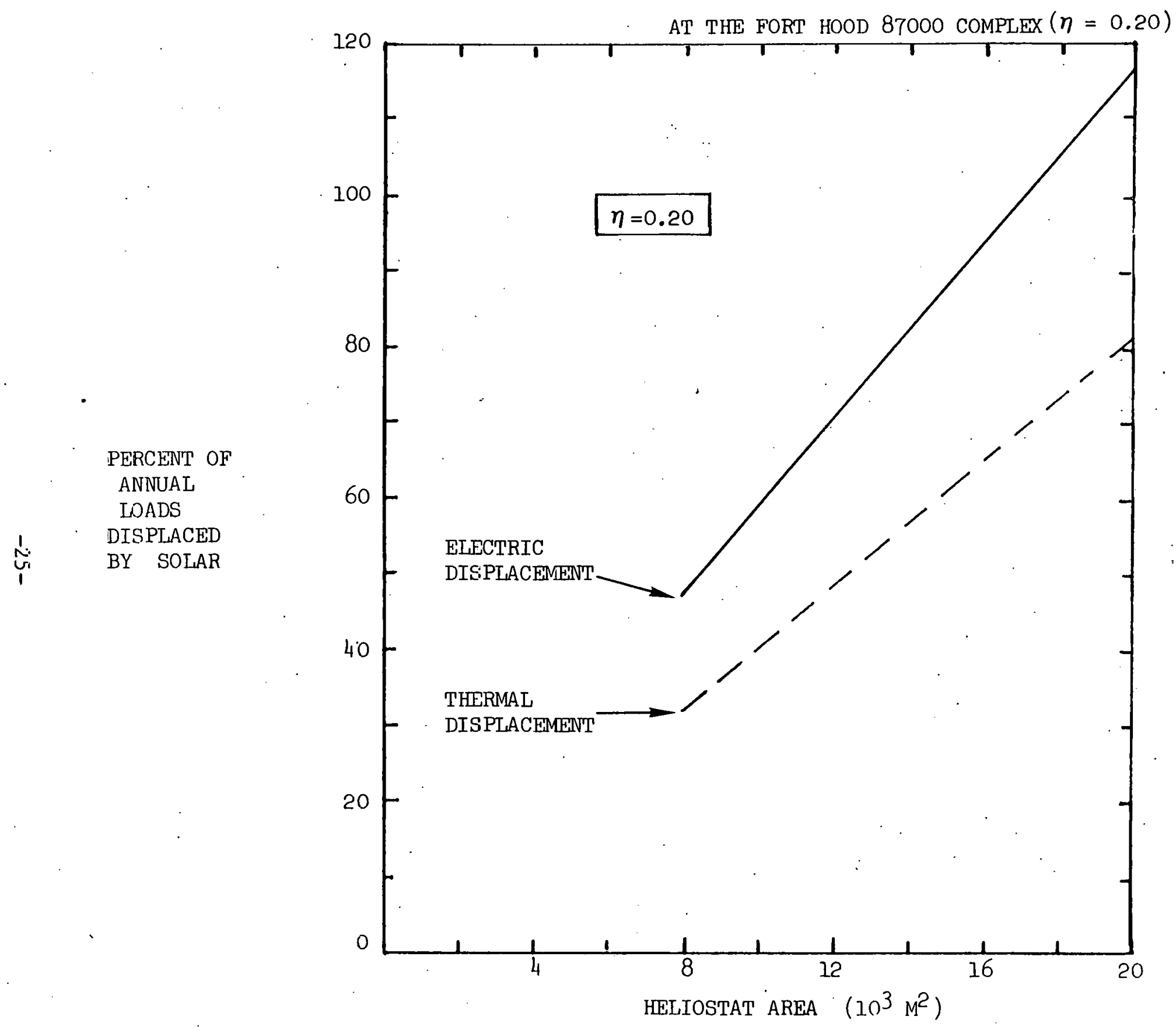


Figure 13

SOLAR COGENERATION PLANT PERFORMANCE

AS A FUNCTION OF TURBINE-GENERATOR EFFICI ENCY SELECTED

(Fort Hood 87000 Complex)

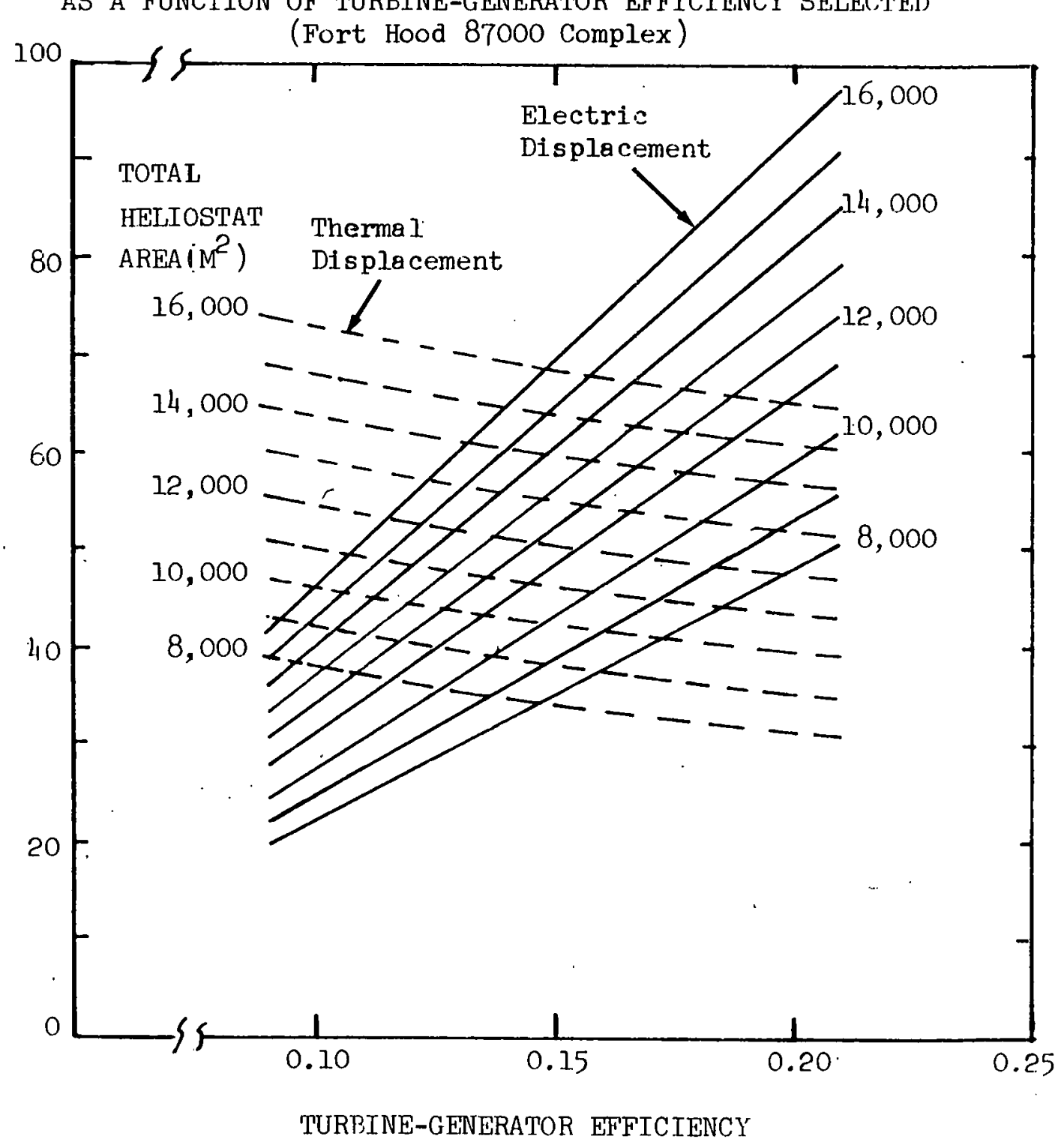


That profile is plotted in Figure 14. The ratio is calculated at the output of the power conversion subsystem, i.e., it is the ratio of total Btu's in the turbine extraction or exhaust steam to the total Btu's of electricity generated. The first quantity is represented by equation ( 6 ) as $(1-\eta) \dot{Q}_{t}$, and the second quantity is represented by equation (5) as $\eta \dot{Q}_{t}$. Hence, the $T / E$ ratio produced can be expressed in terms of $\eta$ as

$$
\begin{aligned}
\mathrm{T} / \mathrm{E} & =\frac{(1-\eta) \dot{\mathrm{Q}}_{t}}{\eta \dot{\mathrm{Q}}_{t}} \\
\mathrm{~T} / \mathrm{E} & =\frac{(1-\eta)}{\eta} \\
\text { or, } \mathrm{T} / \mathrm{E} & =\frac{1}{\eta}-1
\end{aligned}
$$

and the corresponding expression for the turbine-generator efficiency required to produce a given $T / E$ ratio is

$$
\eta=\frac{1}{T / E+1}
$$

Constant $T / E$ ratios representing several values of $\eta$ are drawn on Figure 14. It is clear from inspection of the figure that a high average value of $\eta$ does not lend itself to matching the combined loads of the 87000 complex. The average value of the $T / E$ profile in Figure 14 is 9.35 , and from equation (10) a desired "average" $\eta$ value would then be 0.097 .

\section{SUMMARY}

The results summarized in Figures 13 and 14 indicate that judicious selections of turbine-generator efficiency and field size must be made to achieve a desired set of annual load displacements with a solar cogeneration plant. It may be concluded from this simplified analysis that a turbine-generator operated with an average efficiency of approximately 0.10 would provide the closest match for the Fort Hood application when both electric and thermal loads are considered and given equal "weighting". 


\section{Figure 14}

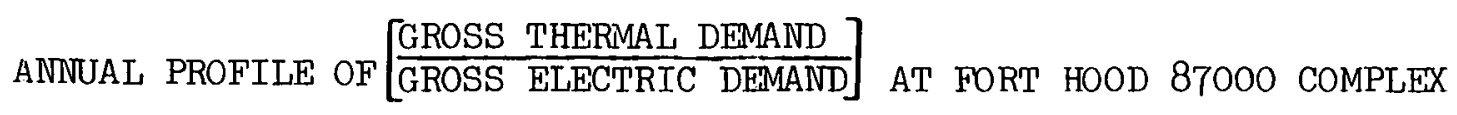

No $\quad \frac{\text { Thermal }}{\text { Electric Ratio }}$

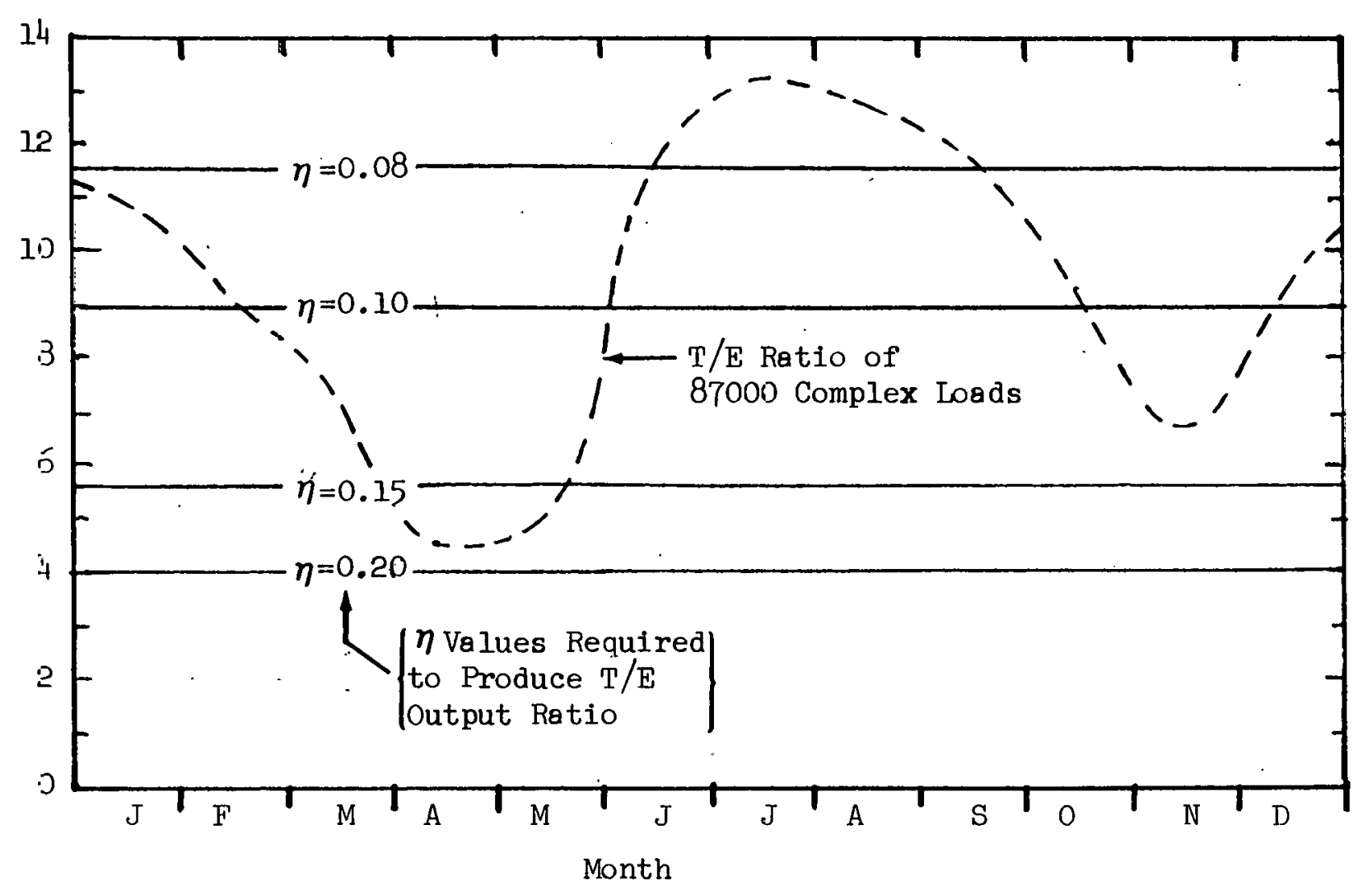


No allowance has been made for meeting a portion of the air conditioning load with electrically-powered vapor compression chillers already existing at the 87000 complex, which may be an attractive design option. In addition to the ratio of thermal demand to electric demand, the costs of backup fossil fuel and purchased electricity to make up deficiencies caused by solar outages, capital equipment costs, and projected annual operation and maintenance costs must be considered. Only technical factors have been included in the present analysis.

Another conclusion is that the electrical parasitic load of the solar cogeneration plant may utilize a significant fraction of the plant's electric output, and therefore warrants careful consideration in the overall plant design and performance calculations. 
A. Fort Hood Solar Cogeneration Facility Conceptual Design Study, Initial Program Review at DOE/SAN, McDonnell Douglas Astronautics Corporation, January 20, 1981 .

B. Fort Hood Solar Total Energy Project, Final Report, American Technological University, January' 1979.

C. Ten Megawatt Solar Thermal Central Receiver Power Plant, SFDI 3rd Project Design Review, McDonnell Douglas Astronautics Corporation, November 13, 1979.

D. Phase I of the First Small Power System Experiment, Final Technical Report, Vol. III, McDonnell Douglas Astronautics Corporation, May 1979.

E. Cogeneration of Electricity and Useful Heat. B. Wilkinson and R. Barnes, CRC Press, 1980.

F. Cogeneration of Steam and Electric Power, Robert Noyes, Noyes Data Corporation, 1978. 